\title{
SPATIAL ANALYSIS TECHNIQUES APPLIED TO MINERAL PROSPECTING: AN EVALUATION IN THE POÇOS DE CALDAS PLATEAU
}

\author{
FÁBIO R. S. MOREIRA, RAIMUNDO ALMEIDA-FILHO \& GILBERTO CÂMARA*
}

\begin{abstract}
Resumo TÉCNICAS DE ANÁLISE ESPACIAL APLICADAS À PROSPECÇÃO MINERAL: UMA AVALIAÇÃO NO PLANALTO DE POÇOS DE CALDAS Diferentes técnicas de análise espacial envolvendo Álgebra Booleana, Média Ponderada, Fuzzy/AHP (Processo Analítico Hierárquico), Fuzzy Gama e Bayesian Weight of Evidence (WofE), foram avaliadas visando a indicação de áreas potenciais à ocorrência de mineralizações radioativas no planalto de Poços de Caldas. Essas técnicas foram aplicadas de acordo com um modelo prospectivo baseado em critérios diagnósticos, representados por litologias favoráveis, feições estruturais e dados de radiometria gama (contagem total). Os mapas resultantes foram organizados em quatro classes de potencialidades (nula, baixa, média e alta), expressando diferentes níveis de favorabilidade à ocorrência de minerais radioativos na área de estudo. Para comparar o desempenho dos diferentes cenários gerados, 48 ocorrências e depósitos minerais previamente conhecidos foram utilizados. Tabulação cruzada foi empregada para medir o grau de confiança (probabilidade condicional) de cada classe. De acordo com os resultados, os cenários mostraram diferentes performances. Aquele obtido com base em Álgebra Booleana mostrou resultados moderados, enquanto os resultados do modelo Fuzzy Gama foram insatisfatórios. Resultados muito bons foram obtidos com os métodos WofE, Fuzzy/AHP e com o modelo de Média Ponderada, atestando que técnicas de inferência podem ser guias auxiliares úteis em campanhas de prospecção mineral.
\end{abstract}

Palavras-chaves: Análise espacial, Geoprocessamento, prospecção mineral

\begin{abstract}
Boolean Logic, Weighted Means, Fuzzy/AHP(Analytical Hierarchic Process), Fuzzy Gamma, and Bayesian Weight of Evidence (WofE) spatial analysis techniques were evaluated to address potential areas for radioactive mineral prospecting in the Poços de Caldas Plateau, Brazil. These techniques were applied according to a prospecting model based on diagnostic criteria, such as favorable lithologies, structural features and gamma ray (total count) data. Resulting maps were organized into four classes of potentiality (null, low, middle and high potential), which express different levels of favorability for radioactive mineral occurrences in the study area. To compare the performance of the resulting scenarios, some 48 known radioactive mineral occurrences were used. Cross-tabulation technique was applied to measure the confidence grade (conditional probability) of each potential class. According to the results, the scenarios showed different performances. The Boolean Logic-based scenario proved to be limited, whereas result of the Fuzzy Gamma technique was unsatisfactory. However, very good results were obtained with the scenarios derived from the Bayesian WofE, Fuzzy/AHP, and Weighted Means techniques, indicating that spatial inference techniques can be useful guides in mineral prospecting campaigns.
\end{abstract}

Keywords: Spatial analysis, Geotechnologies, mineral prospecting

INTRODUCTION Models for spatial data analysis on geographic information systems (GIS) are simplified representations of natural phenomena. The rationale for this simplification is related to the complexity of the natural processes, and the limitations of the mathematical techniques used for representing these phenomena. The consequence is a reduction on our explanatory capability, since the simplified relationships used in the model may lead to misleading or incomplete conclusions.

The formation of a mineral deposit is a good example of such a situation. Since the complexity of the physical and chemical conditions involved in the mineralizations processes cannot be adequately mathematically expressed, the success of a prospecting model depends mainly on model based on empirical relations ("deposit models"). These models consist of a large number of known deposits, considered to be sufficiently similar in terms of their characteristics, which are used as guides (description models) for prospecting similar deposits. Therefore, in GIS-based studies "deposit models" play an important role both in the selection and derivation of the data that will be considered as 'evidence', as well as in the definition of the weights assigned to an evidence. To become an effective tool for geological exploration, a prospecting model must be supported by appropriate geological basis and adequate mathematical support. Following these principles, several authors (e.g. Harris 1989, Bonham-Carter 1990, Almeida-Filho 1995, Singer \& Kouda 1996, Moreira 2001) used prospecting models as auxiliary tools for mineral prospecting.

As a contribution to this theme, this present compares results of different methods of spatial analysis. These methods involved Boolean Logic, Weighted Means, Fuzzy/AHP(Analytical Hierarchic Process), Fuzzy Gamma, and Bayesian Weight of Evidence (WofE) techniques to predict potential areas for radioactive mineral occurrences in the Poços de Caldas alkaline complex, Brazil. The techniques of spatial inference were applied according to a prospecting model based on three diagnostic criteria: presence of particular geological units, presence of structural features, and of anomalous gamma ray total count intensity data. Forty-eight pre-

\footnotetext{
${ }^{*}$ Instituto Nacional de Pesquisas Espaciais - INPE, C. P. 515, São José dos Campos - SP
} 
viously known radioactive mineral occurrences were used as a guide to estimate the performance of the resulting scenarios.

STUDY AREA The study area covers the Poços de Caldas alkaline complex, located on the border of the Minas Gerais and São Paulo states, about 300 km from São Paulo city (Fig. 1a). The alkaline complex forms a roughly circular plateau with area of approximately $750 \mathrm{~km}^{2}$ (diameter $\sim 35 \mathrm{~km}$ ).

The complex, an intrusive Mesozoic-Cenozoic body, is constituted mainly by nepheline-syenite (Fig. 1b), which occurs in three main groups: volcanic materials, effusive and hypabyssal rocks, and plutonic rocks (Fraenkel et al. 1985). Volcanic materials, represented by breccia, tuff and agglomerate, crop out in the northwest part of the massif. Effusive and hypabyssal rocks, formed respectively by phonolite and tinguaite, are distributed all over the alkaline massif. Plutonic rocks, mainly foyaite, occur emplaced into effusive and hypabyssal rocks. Other important unit is the "potassic rock", derived from hydrothermal and weathering alteration of the tinguaite, which constitute an important lithological control of the radioactive mineralization.

$\mathrm{K}-\mathrm{Ar}$ dating (Bushee 1970) allows to estimate in 30 m.a. the magmatic evolution of he alkaline complex, starting in the Upper Cretaceous (87 Ma ago). Ellert (1959) recognized 6 stages in the evolution of the massif: (a) shield reactivation; (b) volcanic activity; (c) formation of the crater; (d) alkaline magmatic activity; (e) annular dike formation; (f) foyaite intrusions. Two large fault systems with predominant direction to N60W and to N40E occur in the alkaline complex. The first one is related to the regional tectonic and the second to the formation of the crater (Fraenkel et al. 1985).

Using Landsat-2 multispectral images, Almeida-Filho \& Paradella (1977) identified in the area several lineaments indicative of faults and fractures, as well as several circular structures within the main crater (Fig. 1c). Location of several radioactive mineral occurrences along these structural features, leaded those authors to consider them as an important structural control of the mineralizations.

Forty-eight radioactive mineral occurrences are known in the Poços de Caldas massif(Fig. 1c), which can be grouped into three main associations: uranium-zirconium, thorium-rare earths and uranium-molybdenum (Tolbert 1966, Oliveira 1974, Fraenkel et al. 1985). The uranium-zirconium association constitutes the most common mineralization, occurring as alluvial and eluvial deposits. Thorium-rare earths constitutes the second association, represented mainly by the Morro do Ferro deposit. Uranium-molybdenum association is the most important, occurring predominantly as veins and lenticular bodies. The Usamu Utisumi mine belongs to this association.

PROSPECTINGMODELAND GEOCODEDDATASET GISbased models of spatial inference and integration rely mainly on empirical relationships, defined with aid of a descriptive "deposit model". The strengthening of this model depends fundamentally on previous geological knowledge about the study area, which will lead to the selection of the most important input data for the model.

The complexity of the phenomena involved in the formation of the alkaline massif and its mineral deposits, makes it difficult to design an empirical prospecting model that takes into account all the components of the mineralization process, which involves tectonic, structural, lithologic and weathering processes. In spite of this, Almeida-Filho (1995) identified certain common characteris- tics of the radioactive mineral deposits, which were assumed as controlling parameters of the mineralization, comprising the diagnostic criteria for a prospecting model:

- favorable lithologies: represented by the potassic rock, volcanic rocks, and borders of the intrusive foyaite bodies;

- structural features: circular structures and lineaments indicating faults and fractures, which controlled the mineralization;

- gamma ray total count: radioactive values higher than 1.8 times the background value (Fig. 1d).

A geocoded dataset, converted to Universal Transverse Mercator (UTM) coordinate system using as cartographic reference the Poços de Caldas, Santa Rita de Caldas and Andrada sheets, at the scale of 1:50.000 (Table 1), was used in this study (Almeida-Filho 1995). All the digital processing was carried out using the SPRING software package (Câmara et al. 1996), which provides a comprehensive set of functions for processing spatial information, including tools for image processing, digital terrain modeling, spatial analysis, geostatistics, spatial statistics, spatial databases, and map management.

MODELING RESULTS Different scenarios for radioactive mineral prospecting in the Poços de Caldas alkaline complex were yielded through various methods of spatial analysis applied according to the adopted empirical prospecting model. The potential areas, expressed as continuous surfaces, were arbitrary sliced in four potential classes (null, low, middle and high potential). In order to compare the performance of the areas of equal potential in the different scenarios, they were defined with approximately the same size $\left(\mathrm{km}^{2}\right)$. For the quantitative evaluation of each scenario, we arbitrarily assumed that each previously known mineral occurrence covered a circular area of $0.2 \mathrm{~km}^{2}$. The performance of the different models relative to the 48 mineral occurrences and deposits known in the area was estimated using a "confidence grade" (Equation 1), which expresses the ratio of the posterior probability of the deposits giving the occurrence of a specific potential class (Equation 2) by the prior probability of the deposit (Equation 3). The symbol $\mathrm{N}\{\}$ indicates the area $\left(\mathrm{km}^{2}\right)$ of each term. The objective of the confidence grade is to assess the improvement of the prospective model, compared with the situation where no information is available.

$$
\begin{gathered}
\text { Confidencgrade }=\frac{P(\text { deposit potentiaklass })}{P(\text { deposi })} \\
P(\text { deposit } \mid \text { potentialclass })=\frac{N\{\text { deposit } \cap \text { potentialclass }\}}{N\{\text { potentialclass }\}} \\
P(\text { deposit })=\frac{N\{\text { deposit }\}}{N\{\text { massif }\}}
\end{gathered}
$$

Boolean Logic Model The model involves logical combinations of binary maps through conditional operators, with each input map (evidence) constituting a layer. Favorable lithologies were grouped to constitute a single class. Since they frequently show gradual or inferred contacts, $100-\mathrm{m}$ buffers were created along them to minimize errors related to location of these contacts. Similarly, all the values of the gamma ray total count 1,8 higher than the regional background were considered as favorable area. This threshold defined by Almeida-Filho (1995) corresponds to the minimum value found in the Campo do Agostinho deposit. For the lineaments and circular structures the binary pattern were arbitrarily defined by buffering these structural features (buffer 

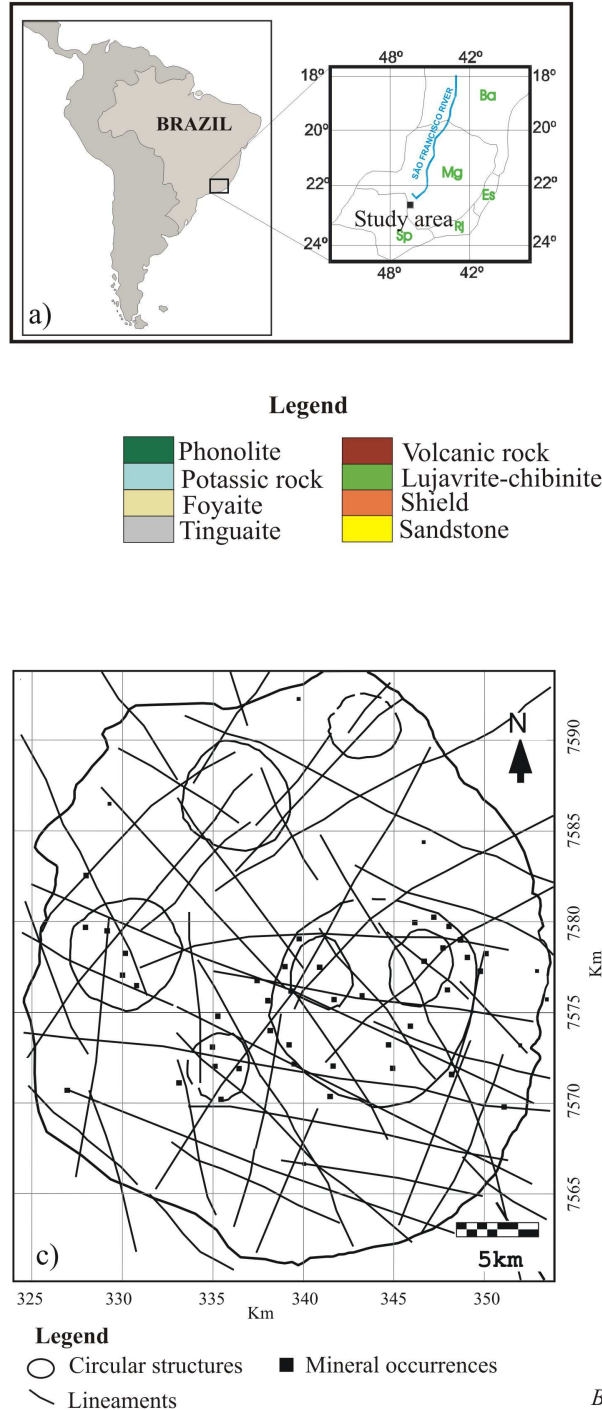
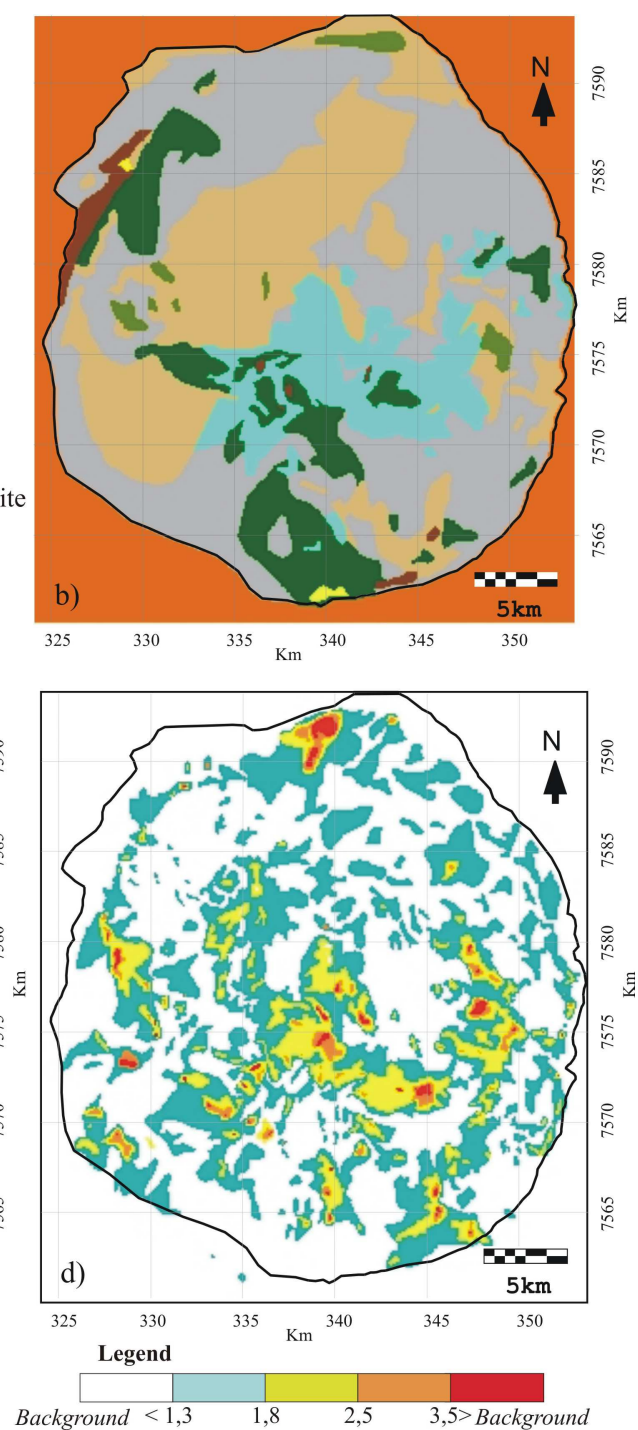

Figure 1 - (a) Location of the study area; (b) lithological map of the alkaline complex (source: Almeida-Filho 1995); (c) structural features and mineral occurrences (modified: Almeida-Filho 1995); (d) gamma ray total count map (source: Almeida-Filho 1995).

Table 1 - Types, formats and attributes of the geocoded dataset used in this study (modified from Almeida-Filho 1995).

\begin{tabular}{l|l|l}
\hline \multicolumn{1}{c|}{ Data } & \multicolumn{1}{c|}{ Format } & \multicolumn{1}{c}{ Attributes } \\
\hline City and main streams & Vector & Infra-structure \\
\hline Lithological map & Vector and raster & Lithological units \\
\hline Gamma ray data & Vector and raster & Radioactivity (total counter) \\
\hline Structural features & Vector & Faults, fractures and circular structures \\
\hline Mineral occurrences & Vector & Field information \\
\hline
\end{tabular}

$$
=250 \mathrm{~m} \text { and buffer }{ }_{\text {circular structure }}=350 \mathrm{~m} \text { ). }
$$

lineament
With all the themes converted to binary, they were combined according to the Boolean operators OR (union) and AND (intersection). Firstly, they were grouped with the OR operator into three main groups that were lately integrated with the AND operator (Equation 4). The logical sequence was as follows: Group A - Favorable lithologies OR Lithological boundaries; Group B - Circular structures OR Lineaments;
Group C-Gamma ray intensity equal or greater to the Campo do Agostinho ore deposit;

$$
\text { Output Map }=(\text { Group A) } A N D(\text { Group B }) A N D(\text { Group C })
$$

The results showed that favorable class $\left(32.4 \mathrm{~km}^{2}\right.$ or $4.45 \%$ of the total area of the alkaline massif) encompassed 24 of the 48 mineral occurrences (Fig. 2). The "confidence grade" indicated that the posterior probability of finding a radioactive mineral occurrence in the favorable class is 5.78 greater than the prior probability. Of the three main ore deposits, the favorable class included the Campo Agostinho and the Morro do Ferro deposits.

The main problem with the Boolean Logic model was its inflexibility grouping into two classes: favorable and unfavorable. This characteristic disabled a directly comparison between results of this technique of spatial analysis with the results obtained with the operators discussed in the next topics.

Weighted Means-based Model The weighted means operator is a 
technique commonly used in projects that involve spatial analysis. Harris (1989), Silva (1994), Eastman et al. (1995), and Almeida-Filho (1995) are good examples of spatial inference studies based on this technique, where diagnostic features are weighted according to their relative importance to the prospecting model.

Choosing the weights is a critical stage, since they depend on the experience of a specialist. The integration here was conducted through a weighted means sum, attempting to enhance the relative importance of the geological phenomena involved in the mineralization processes. The weights adopted in this study were the same defined heuristically by Almeida-Filho (1995), as is summarized in the Table 2.

The values for the scenario ranged from 0 to 65 , where pixels with values equal to " 0 " indicate areas of "null potential", whereas values of " 65 " indicate areas of maximum potential. The resulting image was arbitrarily sliced into four potential groups: 0-29.9 (null), 29.9-52.0 (low), 52.0-55.3 (middle), and 55.3-65.0 (high).

Results showed that the null potential class $\left(628.36 \mathrm{~km}^{2}\right)$ has a confidence grade of 0.44 , which indicates that the area has a potential for mineral prospecting 2.27 lower than the whole area of the alkaline massif (Fig. 3a). Middle and high potential classes $\left(30.64 \mathrm{~km}^{2}\right.$, or $4.27 \%$ of the massif) mapped a total of 24 mineral occurrences. The confidence grades for both classes were 4.97 and 12.6 respectively. Although the high potential class covers an area of only $6.48 \mathrm{~km}^{2}$ (less than $1 \%$ of the massif), it encompasses the Usamu Utsumi, the Campo Agostinho and the Morro do Ferro deposits.

Fuzzy-Based Model Fuzzy logic has been extensively used in GIS-based analysis (e.g. Burrough 1989, Burrough \& Heuvelin 1992, Banai 1993, Altman 1994). The main benefit of fuzzy logic is its ability to codify knowledge, similarly as specialists do in a mental decision processes (Zadeh 1972, Cox 1994, Fang 1997).

Mathematically, a fuzzy group is defined as follows: if $Z$ denotes a space of objects, then a fuzzy group $A$ in $Z$ is the group represented by an ordinary pair: $A=\left(z, M F_{A}(z)\right)$ for all $z \in Z$, where the function $M F_{A}(z)$ maps the graduation of the $z$ members in $A$. The member " 1 " means complete fit to the conjunct, whereas the member " 0 " does not belong to the conjunct. The most used functions to accomplish these conditions are linear and sigmoid functions (Burrough \& McDonnell 1998).

The first step in fuzzy modeling is the mapping of the fuzzy members. In our study, mapping of the fuzzy members of gamma ray total count was obtained through a linear function applied over the weights previously defined by Almeida-Filho (1995), so re-arranging gamma ray intensities to range from 0 to 1 .

The lithological fuzzy members were spatialized, according to the Semantic Import Approach (Burrough \& McDonnell 1998), also considering the type of boundaries, whether inferred or defined. To accomplish this, the lithological data were individualized as binary maps. Distance maps were created along the boundaries of these units. A mask was built defining a 100-m transition zone along the inferred boundaries. The final fuzzy lithological map was obtained by applying the fuzzy member functions to the distance maps, controlled by a $100-\mathrm{m}$ buffer mask along the boundaries. The procedure applied to the potassic rock is shown below as an example:

$M F_{\text {potassic rock }}=0$ IF Mask.CLithology.Class $=$ not-potassic rock

$M F_{\text {potassic rock }}=1$ IF Mask.Class $=$ defined boundary AND Lithology.Class $=$ potassic rock
$M F_{\text {potassic rock }}=(0.005 *$ dist $)+0.5$ IF Mask.Class $=$ inferred boundary AND Lithology.Class = potassic rock AND Distance $>100 \mathrm{~m} \quad$ (3)
$M F_{\text {potassic rock }}=(-0.005 * d i s t)+0.5$ IF Mask.Class $=$ inferred
boundary AND Lithology.Class = not-potassic rock AND
Distance $<100 \mathrm{~m} \quad$ (4)

This procedure ensures that the original boundary location coincides with the crossover point at $M F=0.5$. The point that lies on the lithological units and on the transition zone assumes values from 1 to 0.5 . Outside the lithological unit but in the transition zone the values drop from 0.5 to 0 , according to the distance.

The fuzzy lithological binary data were combined through a weighted means sum (Equation 5). The weights, empirically chosen, intended to express the importance of each lithological unit to the adopted prospecting model.

$M F_{\text {lithological }}=$ potassic rock $+(0.5 *$ foyaaite $)+(0.33 *$ volcanic rock $)(5)$

The procedure of attributing fuzzy members for the circular structures and lineaments was similar. Distance maps were created along these structural features. The sigmoid functions, which spatialized the fuzzy members, were applied on the distance maps considering transition zones of $700 \mathrm{~m}$ and $500 \mathrm{~m}$, respectively. The fuzzy membership function decreases gradually as the distance from structural features increases.

The fuzzy evidential themes were combined according to a multicriteria analysis defined through fuzzy operators (AHP technique and Gamma operators). These procedures generated two different potential scenarios for radioactive mineral occurrence, which are discussed below.

FUZZY/AHP MODEL In this inference model data were combined through a weighted means sum, where the weights were defined using the AHP technique (Saaty 1990), which expresses complex decision making problems by a pairwise comparison.

Firstly, the evidential themes were evaluated in pairs, based in an heuristic evaluation of their relative importance for the prospecting model. A value of relationship, from a nine level graduated scale (equal, slightly better, little better, moderately better, better, quite better, much better, critically better, utterly better), was attributed to these pairings. They were utilized as input data of a pairwise comparing matrix. The resulting relationships are indicated bellow and summarized in Table 3.

Anomalous gamma ray are little better than lithology (3:1);

Anomalous gamma ray data are better than circular structures (5:1);

Anomalous gamma ray data are much better than lineaments (7:1);

Anomalous gamma ray data are much better than the contact buffer of foyaite bodies $(7: 1)$;

Lithology is little better than circular structures $(3: 1)$;

Lithology is better than lineaments $(5: 1)$;

Lithology is better than the contact buffer of foyaite bodies $(5: 1)$;

Circular structures are little better than lineaments $(3: 1)$;

Circular structures are little better than contact buffer of foyaite bodies (3:1);

Lineaments are equal to the contact buffer of foyaite bodies (1:1).

These relationships form a squared, reciprocal pairwise comparing matrix $\mathbf{A}\left(a_{j i}=1 / a_{i j}\right)$ with a unitary rank. The characteristic values $\lambda_{i}(i=1, \ldots n)$ of $\mathbf{A}$ are all equal to zero except one, denominated $\lambda_{\max } \vDash \lambda_{i}=0$. The AHP method proposes that the eigenvector (w) of $\mathbf{A}$ should be applied as the weights for combining the evidential themes. The eigenvector 


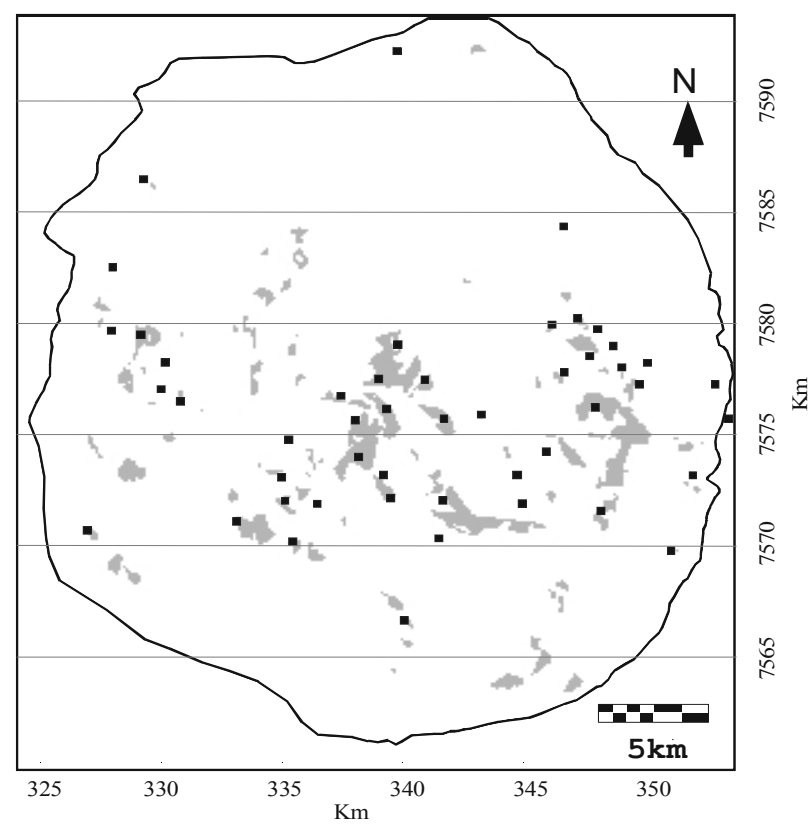

Figure 2 - Potential areas for radioactive mineral prospecting in the Poços de Caldas plateau, based on Boolean Logic model (shaded poligons). the known occurrences are ploted over the scenarios as small black squares.

Table 2 - Weights of the evidential themes for the Weighted $\mu=\prod_{i=1}^{n} \mu_{i(9)}^{M e a}$

\begin{tabular}{lcc}
\hline Evidential Themes & Weight & Term \\
\hline Gamma ray intensity & 80 & $y_{1}$ \\
$>3.5$ background & 80 & $w_{11}$ \\
$2.5-3.5$ & 70 & $w_{12}$ \\
$1.8-2.5$ & 60 & $w_{13}$ \\
$1.3-1.8$ & 10 & $w_{14}$ \\
$<1.3$ background & 0 & $w_{15}$ \\
\hline Lithologies & 60 & $y_{2}$ \\
\hline Potassic rock & 60 & $w_{21}$ \\
Foyaite & 30 & $w_{23}$ \\
Volcanic materials & 20 & $w_{24}$ \\
Tinguaite & 0 & $w_{25}$ \\
Phonolite & 0 & $w_{26}$ \\
Sandstone & 0 & $w_{27}$ \\
Basement rocks & 0 & $w_{28}$ \\
\hline Structural Features & 20 & $y_{3}$ \\
\hline Circular structure buffer $(350 \mathrm{~m})$ & 20 & $w_{31}$ \\
Lineaments buffer $(250 \mathrm{~m})$ & 20 & $w_{32}$ \\
\hline
\end{tabular}

Table 3 - Pairwise comparison matrix used in the Fuzzy/AHPbased model.

\begin{tabular}{lccccc}
\hline & Gamma ray & Lithology & $\begin{array}{c}\text { Circ. } \\
\text { structures }\end{array}$ & Lineaments & $\begin{array}{c}\text { Intrus. } \\
\text { bodies }\end{array}$ \\
\hline Gamma ray & 1 & - & - & - & - \\
Lithology & $1 / 3$ & 1 & - & - & - \\
Circular struc. & $1 / 5$ & $1 / 3$ & 1 & - & - \\
Lineaments & $1 / 7$ & $1 / 5$ & $1 / 3$ & 1 & - \\
Intrusive bodies & $1 / 7$ & $1 / 5$ & $1 / 3$ & 1 & 1 \\
\hline
\end{tabular}

are defined by the Equation 6 :

$$
\text { A.w }=\lambda_{\max } \cdot \mathbf{w}(6)
$$

The weights obtained for the fuzzy themes were: anomalous gamma ray: 0.514 ; lithology: 0.258 ; circular structures: 0.122 ; lineaments: 0.0529 ; contact buffer of foyaite: 0.0529 . These values give the hierarchical relation among the evidential themes, according to the initial pairwise comparisons (Equation 7):

$$
\begin{gathered}
\mathrm{MF}_{\text {result }}=\left(\mathrm{MF}_{\text {gamma }} * 0.514\right)+\left(\mathrm{MF}_{\text {lithology }} * 0.258\right)+ \\
\left(\mathrm{Mf}_{\text {circular struct. }} * 0,1233\right)+\left(\mathrm{MF}_{\text {lineaments }} * 0.0529\right)+ \\
\left(\mathrm{MF}_{\text {intrusive bodies }} * 0.0529\right)(7)
\end{gathered}
$$

Figure $3 \mathrm{~b}$ shows the classes of potentiality for radioactive mineral prospecting in the study area, according to the Fuzzy/AHP model. The confidence grades increased from the null potential class (confidence grade ${ }_{\text {null }}=0.45$ ) to the high potential class (confidence grade $\left._{\text {high }}=12.9\right)$. The high potential class $\left(6.14 \mathrm{Km}^{2}\right.$, or $0.84 \%$ of the alkaline massif) encompasses 12 mineral occurrences (including the Usamu Utsumi, the Morro do Ferro and the Campos Agostinho deposits), whereas the middle potential class (confidence grade $=5.7$ ) included 15 additional mineral occurrences. Both classes covered only $30.43 \mathrm{~km}^{2}$ (4.18\% of the alkaline massif) and mapped 27 deposits. The null potential class comprises 629 $\mathrm{km}^{2}(86,48 \%$ alkaline complex) and included 10 mineral occurrences.

FUZZY GAMMA MODEL In this inference model discussed by An et al. (1991), data were combined through a Gamma operator (Equation 8) defined by two terms (fuzzy algebraic product (Equation 9) and fuzzy algebraic sum (Equation 10), which are controlled by the gamma parameter (" $\gamma$ "). This parameter determines whether the decision of a specialist is pessimist $(\gamma<0,35)$ or optimistic $(\gamma$ $>0,85$ )

$$
\mu=(\text { fuzzy algebraic sum })^{\gamma} \mathrm{x}(\text { fuzzy algebraic product })^{1-\gamma}
$$

where $\mu_{\mathrm{i}}$ addresses the fuzzy member value of the " $i_{t h}$ " evidence.

$$
\mu=1-\prod_{i=1}^{n}\left(1-\mu_{i}\right)
$$

where the term $\mu_{\mathrm{i}}$ addresses the fuzzy member value of the " $i_{t h}$ " evidence.

In order to minimize the influence of the fuzzy algebraic product on the final result, we adopted $\gamma$ as 0,85 . As multiplying numbers are lower than 1 , this membership tends to decrease the output values. The formulas below expresses the procedure:

$$
\begin{gathered}
M F_{\text {fuzzi alg.sum }}=1-\left(\left(1-M F_{\text {gama }}\right) *\left(1-M F_{\text {litho }}\right) *\right. \\
\left.\left(1-M F_{\text {circular est }}\right) *\left(1-M F_{\text {lineam. }}\right) *\left(1-M F_{\text {intrus. bodies }}\right)\right) \\
M F_{\text {fuzzi alg.product }}=M F_{\text {gama }} * M F_{\text {litho }} * M F_{\text {circular est }} * \\
M F_{\text {gama }}=\left(M F_{\text {fuzzy algebric sum }}\right) \\
0.85 *\left(M F_{\text {fuzzy algebric product }}\right)
\end{gathered}
$$

The results (Fig. 3c) show that the high potential class of this model encompassed only 8 mineral occurrences, including only the Morro do Ferro deposit. The middle and high potential classes, comprising $29.06 \mathrm{~km}^{2}$ (3.78\% of the alkaline massif), mapped 17 mineral occurrences. The null potential class mapped 15 mineral occurrences, including the Campo do Agostinho and the Usamu Utsumi deposits.

Bayesian Model The Bayesian method determines the probability of an event to occur under certain conditions. In prospecting 
terms, it can be thought as the probability of a deposit to occur, conditioned by the presence of a specific evidence (e.g. favorable lithology). The method considers each evidence separately and computes how much the evidence contributes to increase the chance of discovering a new mineral deposit. In this process, a 'weight of evidence'(WofE) is determined, indicating the increase or decrease in probability of finding a mineral deposit, based on the occurrence of the evidence.

A basic condition of this method is the indespendence among the evidential themes. Studies were conducted to measure the conditional independence $(\mathrm{CI})$ between pairs of binary evidential themes. To address the CI, $\chi^{2}$ statistic and contingency coefficient $(C)$ were applied. Area cross-tabulation provided the confusion tables to obtain the parameters to estimate the $\chi^{2}$.

The interception values $\left(T_{i, j}\right)$, plus the expected values $\left(T_{i, j}^{*}\right)$ were applied to calculate $\chi^{2}$ statistic (Equation 11) and the $C$ (Equation 12). Similar calculations were repeated for all the evidential themes. The contingency coefficients demonstrated that the hypothesis of independence of the evidential themes could be applied to the dataset.

$$
\begin{aligned}
& \chi^{2}=\sum_{i=1}^{2} \sum_{j=1}^{2} \frac{\left(T_{i, j}-T_{i, j}^{*}\right)^{2}}{T_{i, j}^{*}} \\
& C=\sqrt{\frac{\chi^{2}}{T_{. .}+\chi^{2}}}
\end{aligned}
$$

To perform the analysis, areas $\left(0.20 \mathrm{~km}^{2}\right)$ of the mineral occurrences were cross-tabulated with the evidential themes in binary format, yielding statistical parameters to define the weights. The conversion of a multi-class map to a binary map can be done either subjectively, through the judgment of a specialist, or statistically, through the determination of the threshold that maximizes the spatial association between known mineral occurrences and the binary evidential themes. Determination of the Contrast $\left(C_{w}\right)$, which expresses the difference between the positive $w^{+}$and the negative $w$ WofE (Bonham-Carter 1996), is one of the most efficient procedures to define the threshold that maximizes the spatial correlation between an binary evidential theme and mineral occurrences.

The contrast for the circular structures and lineaments were obtained by defining $25 \mathrm{~m}$-width buffer zones along them. The buffers were cross-tabulated with the 48 known mineral occurrences, providing parameters to calculate the contrast for the buffer zone. These values were plotted on a cumulative graph, so determining the highest cumulative value that defines the buffer width with the best spatial correlation with the mineral occurrences. Buffer zones of $250 \mathrm{~m}$ and $650 \mathrm{~m}$ showed the highest Contrast for lineaments and circular structures, respectively.

To estimate the degree of spatial correlation between the mineral deposits and the evidential themes, we calculate the Sufficiency and Necessity likelihood ratios, which provide a measure of spatial association between the two binary maps. The Sufficiency ratio $(L S)$, expresses the relation between the probability of a binary pattern $\mathrm{B}$ being present, given the presence of a binary pattern $\mathrm{D}$, by the probability of the binary pattern $\mathrm{B}$ being present, given the absence of the binary pattern $\mathrm{D}$ (Equation 13 ). The Necessity ratio $(L N)$, expresses the relation between the probability of a binary pattern B being absent, given the presence of a binary pattern $\mathrm{D}$, by the probability of the binary pattern $\mathrm{B}$ being absent, given the absence of the binary pattern D (Equation 14). The natural logarithms of the $L S$ and $L N$ give the positive $\left(w^{+}\right)$and the negative $\left(w^{-}\right)$WofE for those patterns. Table 4 summarizes the results of the
WofE analysis for the study area.

$$
\begin{aligned}
& L S=P(B \mid D) / P(B \mid \bar{D}) \\
& L N=P(\bar{B} \mid D) / P(\bar{B} \mid \bar{D})
\end{aligned}
$$

The likelihood ratios indicated that areas of anomalous gammaray, favorable lithologies, circular structures and lineaments offer (in different grades) positive evidence for the occurrence of radioactive minerals in the Poços de Caldas alkaline massif. The $w^{+}$is positive and the $w$ is negative due to the positive correlation between mineral occurrences and the evidential themes. Otherwise, $w^{+}$would be negative and $w^{-}$would be positive. If a pattern is independent of whether the other is present or not, then $w^{+}=w^{-}=0$.

The Contrast $\left(C_{w}\right)$ is also an important parameter to quantify spatial association between the binary patterns. It would be equal to zero whether the binary patterns overlap each other only by chance, being negative for negative association and positive for positive association - as is the case for the study area. According to the results, contrast values indicate that the gamma ray data are the evidence more strongly associated with the radioactive mineralizations, followed by the presence of the circular structures identified through satellite images. Lithology present a moderate association, whereas linear features associated with faults and fractures are weakly associated with the mineralizations.

The scenario of the Bayesian modeling (Figure 3d) showed that high potential class encompasses 9 mineral occurrences, including the Morro do Ferro deposit, in an area of $5.98 \mathrm{~km}^{2}(0.82 \%$ of the Poços de Caldas massif). The middle potential class encompasses 18 mineral occurrences in an area of $21.56 \mathrm{hm}^{2}(2.95 \%$ of the Poços de Caldas massif). The null potential class, with $635.18 \mathrm{~km}^{2}(87.33 \%)$, presents posterior probability 2.08 smaller than the prior probability. This implies that a hypothetical prospecting campaign conducted in this class would have less success than considering the whole massif.

CONCLUDINGREMARKS Table 5 summarizes the performance of the different spatial analysis models used in this study.

The limitation of the Boolean-Logic model was the low flexibility of this model, which does not allow the redistribution of the data in different classes of priorities. In spite of this, the favorable class mapped 24 of the 48 mineral occurrences, including the Morro do Ferro and the Campo do Agostinho deposits.

The Weighted Means-based model allows good flexibility for data handling, so improving the inference process and graduating the data according to the previously defined importance. The procedures generated a very good scenario, with the high potential class showing the second highest confidence grade compared to the other models. This potential class $\left(6.48 \mathrm{~km}^{2}\right.$, or less than $1 \%$ of the of the alkaline massif) mapped $25 \%$ of the mineral occurrences, including the Usamu Utsumi, the Campo do Agostinho and the Morro do Ferro deposits.

The fuzzy procedure favored a good refinement in the data modeling, allowing to represent the attribute spatial variation in

Table 4 - Results of the Bayesian Weight of Evidence (WofE) analysis.

\begin{tabular}{lccc}
\hline Geological evidence & $\mathrm{w}^{+}$ & $\mathrm{w}^{-}$ & $\mathrm{C}_{\mathrm{w}}$ \\
\hline Anomalous gamma ray & 1.685 & -0.704 & 2.389 \\
Circular structures & 0.882 & -0.437 & 1.319 \\
Lithology & 0.361 & -0.384 & 0.745 \\
Lineaments & 0.150 & -0.103 & 0.253 \\
\hline
\end{tabular}


Fábio R. S. Moreira et al.
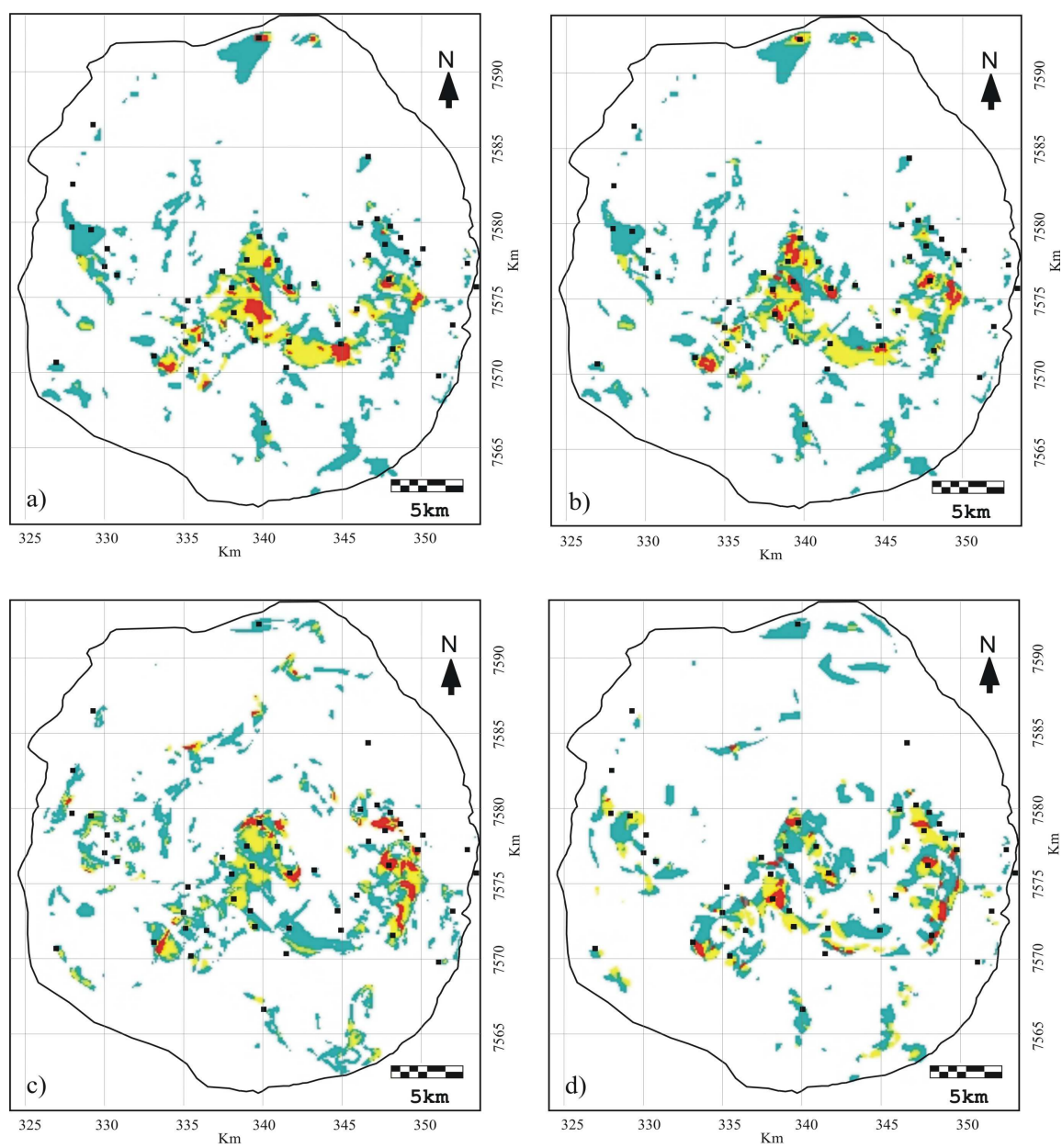

Figure 3 - Null (white), low (green), middle (yellow), and high (red) potential areas for radioactive mineral prospecting in the Poços de Caldas alkaline complex derived from Weighted Means-based model (a); Fuzzy/AHP-based model (b); Fuzzy Gammabased model (c); and Bayesian WofE-based model (d). The known mineral occurrences are plotted over the scenarios as small squares.

Table 5 - Summary of the results for each scenario

\begin{tabular}{|c|c|c|c|c|c|}
\hline C lass & Area $\left(\mathrm{km}^{2}\right)$ & Area $(\%)$ & Posterior Prob. & Confidencegrade & Occurrences \\
\hline Favorable & 32.4 & 4.45 & 0.0722 & 5.78 & 24 \\
\hline Notfavorable & 694.94 & 95.55 & 0.0097 & 0.78 & 24 \\
\hline Total & 727.34 & 100.00 & Prior Probability & 0.0125 & 48 \\
\hline \multicolumn{6}{|l|}{ Weighted Means } \\
\hline Class & Area $\left.\left(k^{2}\right)^{2}\right)$ & Area $(\%)$ & Posterior Prob. & Confidence grade & Occurrences \\
\hline High potential & 6.48 & 0.89 & 0.1574 & 12.60 & 12 \\
\hline Middle potential & 24.16 & 3.32 & 0.0621 & 4.97 & 12 \\
\hline Low potential & 68.34 & 9.40 & 0.0457 & 3.65 & 16 \\
\hline Null potential & 628.36 & 86.39 & \begin{tabular}{|l}
0.0055 \\
\end{tabular} & 0.44 & 8 \\
\hline Total & 727.33 & 100.00 & Prior Probability & 0.0125 & 48 \\
\hline \multicolumn{6}{|l|}{ Fuzzy/A H P } \\
\hline Class & Area $\left(\mathbf{k m}^{2}\right)$ & Area (\%) & Posterior Prob. & Confidence grade & Occurrences \\
\hline High potential & 6.14 & 0.84 & 0.1612 & 12.90 & 12 \\
\hline Middle potential & 24.29 & 3.34 & 0.0712 & 5.70 & 15 \\
\hline Low potential & 67.91 & 9.34 & 0.0423 & 3.38 & 11 \\
\hline Null potential & 629.0 & 86.48 & 0.0056 & 0.45 & 10 \\
\hline Total & 727.33 & 100.00 & Prior Probability & 0.0125 & 48 \\
\hline \multicolumn{6}{|l|}{ Fuzzy G a m ma } \\
\hline Class & Area $\left(\mathrm{km}^{2}\right)$ & Area $(\%)$ & Posterior Prob. & Confidence grade & Occurrences \\
\hline High potential & 6.48 & 0.89 & 0.0864 & 6.92 & 8 \\
\hline Middle potential & 22.58 & 3.10 & 0.0540 & 4.33 & 9 \\
\hline Low potential & 68.75 & 9.45 & 0.0374 & 2.99 & 17 \\
\hline Null potential) & 629.52 & 86.55 & \begin{tabular}{|l|}
0.0075 \\
\end{tabular} & 0.60 & 14 \\
\hline Total & 727.33 & 100.00 & Prior Probability & 0.0125 & 48 \\
\hline \multicolumn{6}{|l|}{ Bayesian WofE } \\
\hline C lass & Area $\left(\mathrm{km}^{2}\right)$ & Area $(\%)$ & Posterior Prob. & Confidence grade & Occurrences \\
\hline High potential & 5.98 & 0.82 & 0.0836 & 6.69 & 9 \\
\hline M iddle potential) & 21.56 & 2.96 & 0.1048 & 8.39 & 18 \\
\hline Low potential & 64.61 & 8.88 & 0.0393 & 3.15 & 11 \\
\hline Null potential & 635.18 & 87.33 & 0.0060 & 0.48 & 10 \\
\hline Total & 727.33 & 100.00 & Prior Probability & 0.0125 & 48 \\
\hline
\end{tabular}


continuous surfaces. Additionally, the Semantic Import (SI) approach allowed to account the inferred lithological boundaries in the modeling, which resulted in more precise information regarding the spatial distribution of the geological data.

The high potential class of the Fuzzy/AHP scenario showed the best performance compared to the others ones. Showing the highest confidence grade and covering only $0.84 \%$ of the alkaline massif, it mapped 12 mineral occurrences, including the ore deposits of the Usamu Utsumi, the Campo do Agostinho and the Morro do Ferro. The main responsible for this performance was the AHP technique which organized the evidential themes according to their relative importance in the prospecting model. On the other hand, the Fuzzy Gamma scenario presented the poorest performance among all the scenarios.

The Bayesian WofE method constitutes a very interesting approach in spatial data analysis. The possibility of applying statistical parameters to define the weights of the evidence, instead a heuristic basis, is highly recommended. The $w^{+}$and the $w^{-}$WofE constitute essential parameters to quantitatively estimate the importance of each evidential layer. The contrast is other important parameter that enables the definition of pattern that maximizes the spatial association between data.

For the study area, results showed that the techniques of spatial analysis can constitute powerful tools to assist mineral prospecting campaigns. From an exploration point of view, the use of computerbased methods can provide significant saving in time and money in these campaigns.

Acknowledgements This study was part of the master degree program conducted by the first author at INPE, with support of the CAPES (Coordenadoria de Aperfeiçoamento de Pessoal de Nível Superior). The authors also thank Dr. Graeme Bonham-Carter, Dr. Christien Thiart, and the anonymous reviewer for constructive criticisms of the manuscript.

\section{References}

Almeida-Filho R. \& Paradella W.R. 1977. Estudo do maciço alcalino de Poços de Caldas através da imagens Landsat com ênfase em mineralizações radioativas. São José dos Campos: Inpe-111-TPT/ 060, 130p.

Almeida-Filho R. 1995. Integração, manipulação e análise espacial de dados na pesquisa mineral através de modelos empíricos de prospecção: Um exemplo no planalto de Poços de Caldas. Rev. Bras. Geofisica, 13:127-142

Altman D. 1994. Fuzzy set theoretic approaches for handling imprecision in spatial analysis. Intern. J. Geograp. Info. Systems, 8: 271-279

An P., Moon W.M., Rencz A. 1991. Application of fuzzy set theory for integration of geological, geophysical and remote sensing data. Can. J. Explor. Geophysics, 27: 1-11

Banai R. 1993. Fuzziness in Geographical Information System: contributions from analytic hierarchy process. Intern. J. Geograp. Info. Systems, 7:315-329

Bonham-Carter G.F. 1990. Mapping mineral potential with a geographic information system. In: Computer Application in Mining Exploration, Workshop of Computer Treatment of Exploration and Mining Data, Ottawa, Proceedings, 121-130

Bonham-Carter G.F. 1996. Geographic information systems for geoscientists: modelling with GIS. Computer Methods in the Geosciences, Vol. 13, Pergamon, 398 p.

Burrough P.A. 1989. Fuzzy mathematical methods for soil survey and land evaluation. Journal of Soil Science, 40: 477-492

Burrough P.A. \& Heuvelink G.B.M. 1992. The sensitivity of Boolean and continuous (Fuzzy) logical modeling to uncertain data. In: EGIS 92, Munich, Germany, Proceeding, 1:1032-1041

Burrough P. A. \& McDonnell R. A. 1998. Principles of geographical information systems. Oxford, University Press, 333p.

Bushee J. 1970 A geochronological study of the alkaline massif of Poços de Caldas, Brazil. São Paulo, Laboratório de Geocronologia da Universidade de São Paulo, 25 p. (Relatório não publicado)

Câmara G., Souza R.C.M., Freitas U.M., Garrido J.C.P. 1996. SPRING: Integrating Remote Sensing and GIS with Object-Oriented Data Modelling. Computers and Graphics, 15: 13-22

Cox E. 1994. The fuzzy systems handbook: a practitioner's guide to building, using, and maintaining fuzzy systems. London, Academic Press, 625p.

Eastman J.R., Jin W., Kyem P.A.K., Toledano J. 1995. Raster proce- dures for multi-criteria/multi-objective decisions. Photogram. Enginee. Rem. Sensing, 61:539-547

Ellert R. 1959. Contribuição á geologia do maciço alcalino de Poços de Caldas. São Paulo, Geologia, USP-FFCL, 18:5-63

Fang J. H. 1997. Fuzzy logic \& geology. Geotimes: News and Trends in the Geoscience, 42:23-26

Fraenkel M.O., Santos R.C., Lourenço F.E.V.L., Muniz W.S. 1985 Jazida de urânio no planalto de Poços de Caldas, Minas Gerais. In: Principais Depósitos Minerais do Brasil. DNPM, 1:89-103

Harris J. 1989. Data integration for gold exploration in eastern Nova Scotia using a GIS. In: ERIM, Thematic Conference on Remote Sensing for Exploration Geology, 7, Calgary, Canada, Proceedings, 233-248

Moreira F.R.S. 2001. Uso e avaliação de técnicas de integração e análise espacial de dados em pesquisa mineral aplicadas ao planalto de Poços de Caldas. Instituto Nacional de Pesquisas Espaciais - INPE, São José dos Campos, Dissertação de Mestrado, 164 p.

Oliveira A. G. 1974. Mineralização de urânio e molibdênio no Planalto de Poços de Caldas. In: SBG, Congresso Brasileiro de Geologia, 28, Minas Gerais, Anais: 1:207-221

Saaty T.L. 1990. Multicriteria decision making - the analytical hierarchy process. 2 ed. Pittsburgh, RWS Publications, 437 p.

Singer D.A. \& Kouda R. 1996. Application of a Feedforward Neural Network in the Search for Kuroko Deposits in the Hokuroku District, Japan. Mathematical Geology, 28:1017-1023

Silva A.B. 1994. A GIS approach for land use assessment a Brazilian case study. In: ERIM, Thematic Conference on Geology Remote Sensing, 10, San Antonio, Texas, Proceedings, 2:296-303

Tolbert J. 1966 The uraniferous zirconium deposits of the Poços de Caldas plateau, Brazil. cidade U.S. Geological Survey Bulletin, 28p. (Bulletin 1185-C)

Zadeh L.A. 1972. A fuzzy-set theoretic interpretation of linguistic hedges. J. Cybernetics, 2:4-34

Manuscrito SR-24

Recebido em 23 de novembro de 2002

Revisão dos autores em 22 de março de 2003

Revisão aceita em 22 de abril de 2003 